DOI: $10.2478 / \mathrm{v} 10129-010-0001-y$

\author{
Sławomir Wróbel
}

Plant Breeding and Acclimatization Institute, Department of Potato Protection and Seed Science, Bonin, 76-009 Bonin 3, wrobel@ziemniak-bonin.pl

\title{
THE RETENTION OF PVY IN THE STYLET OF MYZUS PERSICAE SULZ. AFTER THE APPLICATION OF MINERAL OIL ON POTATO PLANTS
}

\begin{abstract}
An important element of epidemiological studies is the understanding of PVY retention, that is to say, the time of the infectious virus remaining in the aphid's stylet, after it is contracted by the aphid from an infected plant. The purpose of the research was to establish PVY retention in the stylet of Myzus persicae after using mineral oil for potato plant protection.

It has been found that using mineral oil had a considerable effect on the shortening of the virus retention in the stylet of $M$. persicae. In the situation of the lack of oil protection, PVY was active on the aphid's stylet even 17 hours after its acquisition, while the ability of virus transmission after that period was very low. Oil protection of both healthy plants and those being the source of the virus reduced PVY retention in the stylets, which were its active vectors for only about 2 minutes, by a great extent.

Considerable shortening the time of the virus activity in the aphids' stylet, after applying mineral oil on the plants being the source of the virus, practically inhibits the potential infection range of healthy plants. In the situation of having multiple sources of the virus in production conditions, their role in spreading PVY is brought down to a minimum, after the application of the mineral oil protection.
\end{abstract}

Key words: $\quad$ mineral oil, Myzus persicae, potato, PVY, retention

\section{INTRODUCTION}

In the epidemiology of virus diseases affecting potatoes a major role is played by aphids which are their vectors. Aphid control mainly limits infection by Potato leafroll virus, PLRV. In the case of Potato virus Y, PVY which is transmitted by aphids in a non-persistent manner, mineral oil plays a very important role in its inhibition, however, the mechanism of the oil effect is still not fully understood. In their research, Powell et al. (1998) have observed that the aphids feeding on leaves previously covered with mineral oil started the acquisition feeding much later compared to the feeding on non-protected plants. A similar behaviour had previously been observed by Simons et al. (1977), Powell (1992), Powell and Hardie (1994). According to Gibson et al. (1988) and Qui and Pirone (1989) the use of oil had no sig-

Communicated by Ewa Zimnoch-Guzowska 
nificant effect on the behaviour of Myzus persicae Sulz. aphids while feeding. One of the hypotheses regarding the impeding effect of mineral oil on the transmission of non-persistent viruses by aphids assumes that the cause of limiting this capacity of the aphids may be a direct interference of the interaction between the virus particles, and their capability of remaining in the aphid's stylet under the influence of the oil used (Qui and Pirone 1989; Wang et al. 1996; Wang and Pirone 1996; Powell et al. 1998).

An important element of epidemiological research which could provide new information on the role of mineral oil in the protection of the potato against viruses is the understanding of PVY retention, that is, the time the infectious virus remains in the aphid's stylet after it is contracted by the aphids from an infected plant. It is known from the available literature that viruses transmitted by aphids in a non-persistent manner (in the stylet) in natural conditions (unprotected plants) have very different virus retention times (Kostiw 1987). However, there is no information concerning the activity time of PVY in the aphids feeding on plants treated with mineral oil. The understanding of this phenomenon was the objective of the present work.

\section{MATERIAL AND METHODS}

The tests were carried out in the greenhouse, between May and July. In the experiment, winged morphs of the virus-free clone of $M$. persicae aphids were used, which are the most effective PVY vectors (Cerato et al. 1994; Collar et al. 1997; Derron and Goy 1990; Kostiw 1987; Sigvald 1984). The insects were raised on Beijing cabbage (Brassica pekinensis Rupr.) in isolated chambers, in a separate room. Only aphids being in good condition were selected for infection. Apterae M. persicae were put into glass vials and starved for approximately 2 hours, because according to Powell (1993), starved aphids start feeding faster, and besides that aphid starving contributes to the increase in virus acquisition by them, which as a consequence increases the probability of test in vitro -grown potato plants of the Mila cultivar were used, which had been systematically planted into the greenhouse pots. The choice of the cultivar was dictated by its low resistance to PVY (result 5.5 on a 1-9 scale, where 9 indicated extreme resistance (Kamasa 2003). The source of PVY comprised the infected potato plants of Van Gogh cultivar. The source plants were kept in isolated compartments of the greenhouse. In the research, the commercially available Sunspray 850 EC mineral oil was used (content: $98,8 \%$ mineral oil $+1.2 \%$ emulsifier), recommended for the protection of potato seed plantations. Depending on the needs and combination (tab. 1), both the test plants and the plants being the source of the virus, they were sprayed with mineral oil with a concentration of $3.75 \%$, by using a hand-held pressure sprayer 24 hours 
before use. The spraying operation was done until the first drops of working liquid started to flow down the leaves.

After 2 hours of starving M. persicae, the aphids were gently taken out of the vials and allowed a 2-minute long acquisition feeding on the source plants (potato plants of the Van Gogh cultivar). Since according to the previous studies by Kostiw (1976) the optimum of acquisition feeding for PVY in the case of M. persicae is from 30 seconds up to 2 minutes. Next, the insects were starved again and during that time placed in a glass vial protected with a dense nylon net. 11 different starving times were assessed: $1 \mathrm{~min}, 2$ min, $4 \mathrm{~min}, 8 \mathrm{~min}, 16 \mathrm{~min}, 32 \mathrm{~min}, 64 \mathrm{~min}, 128 \mathrm{~min}, 256 \mathrm{~min}, 512 \mathrm{~min}$ and $1024 \mathrm{~min}$. The time was set according to the formula:

$$
t n=2 n t_{0}
$$

counting from $t_{0}=1 \min$ to $t_{10}=1024 \min$. The times were checked by using a 24-hour stopwatch. After each starving period was over, the aphids were transferred from the vials for a two-minute-long inoculation feeding time on the potato test plants. In order to increase the pressure and thus, the probability of infection, 2 aphids were used on each plant for each starving times in each combination of oil protection. The aphids' behavior, particularly the proboscis activity, on PVY source plants as well as the potato test plants was observed through a 4 and $12 \times$ magnifying glass. One-time observations of no more than 2 plants with 2 aphids per plant were performed. The contact of the aphids' stylet with the surface of the leaf, with the simultaneous placing of the tentacles along the insect's body and adopting a characteristic position was taken as the beginning of feeding. Only actual and continuous two-minute-long feeding times of the aphids were taken into consideration and not the time of staying on the plant or the time of the first, very short probing penetration. After the termination of inoculation feeding, the aphids were removed from the plant and killed. For each starving time (11 times) in each combination of oil protection (4 different combinations) (Table 1), 10 plants were inoculated, giving a total of 440 potato plants.

The assessed combinations in studies on potato virus $Y$ retention in $M$. persicae after using mineral oil

\begin{tabular}{ccl}
\hline Comb. No & $\begin{array}{c}\text { Source of the virus (cv. Van Gogh potato } \\
\text { plants infected with } P V Y)\end{array}$ & $\begin{array}{c}\text { Test plant (cv. Mila healthy } \\
\text { potato plants from in vitro) }\end{array}$ \\
\hline 1. & unprotected (control) & unprotected (control) \\
2. & unprotected & treated with mineral oil \\
3. & treated with mineral oil & unprotected \\
4. & treated with mineral oil & treated with mineral oil \\
\hline
\end{tabular}


After the inoculation, the plants were kept in the greenhouse until the end of vegetation so that they could set tubers. After the vegetation period was over, the collected tubers, separately from each plant, were placed in individual, properly marked containers. During the winter-spring season, the collected mini-tubers planted in a greenhouse. Plants grown from the mini-tubers were DAS ELISA-tested for PVY, while using a polyclonal antibody. In the greenhouse test, 3 mini-tubers from each plant were planted in order to reduce the error due to the uneven transmission of viruses from the plant to the tubers. The average infection ratios from the three planted tubers were not analysed, just the fact of the infection or the lack of it. Altogether the research involved the investigation of 1320 potato mini-tubers derived from 440 inoculated plants. Although the results suggested an unequivocal interpretation, they were also subjected to a statistical analysis. In order to do this the results were first transformed according to $\log (\mathrm{P}+1)$ formula, where $\mathrm{P}$ stands for the percentage of infected plants, and subsequently an ANOVA analysis of variance was conducted for the transformed results. In the study showed retransformation data (infection ratio) according to relation $-10^{(\mathrm{X}-1)}$, where $\mathrm{X}$ represents transformed values.

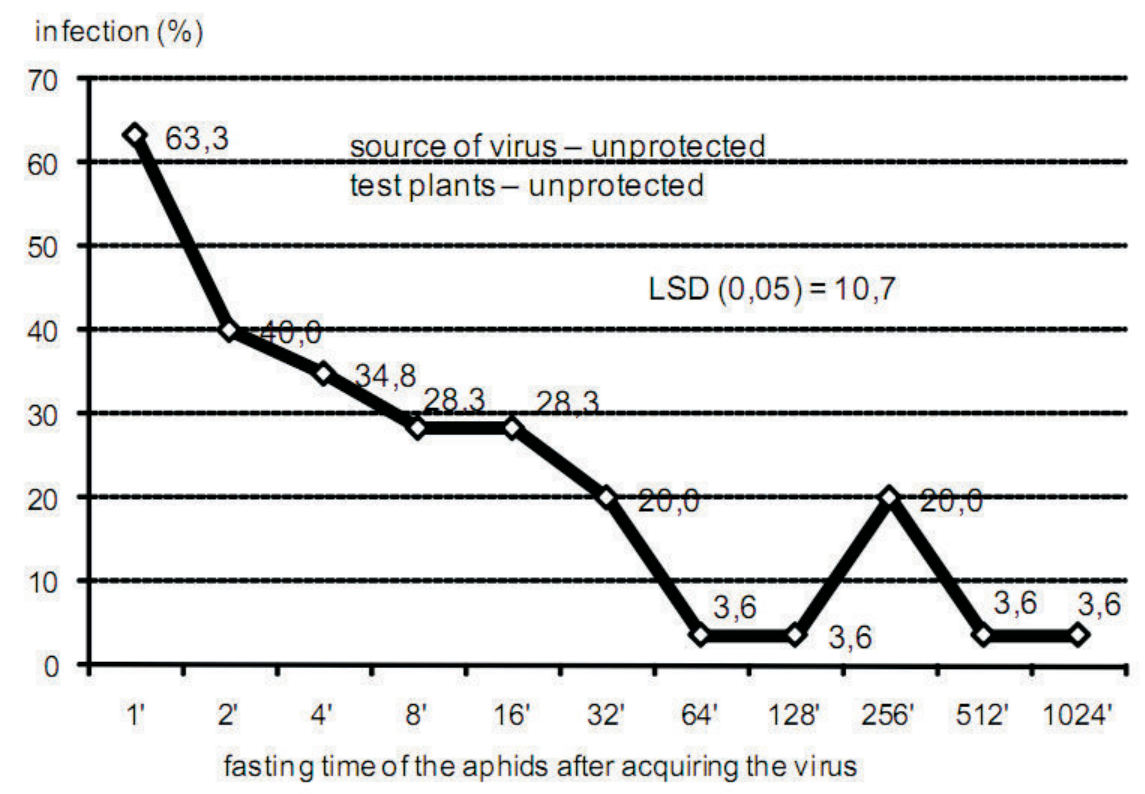

Fig. 1. Potato virus Y retention in winged M. persicae - control combination

\section{RESULTS AND DISCUSSION}

It was established that on the control objects, without the use of the mineral oil, M. persicae had the infectious PVY in their stylets even after 17 hours after its acquisition from the plants which were the source of the virus 
(Fig. 1). It has to be noted, however, that PVY infection's efficiency was much more feeble after such long a time (infection ratio 3.6\%) than after a few minutes fasting (infection ratio $63.3 \%$ ), and the number of infested plants decreased with the time of fasting. The results show the possibility of transmitting PVY over very large distances from the sources of the virus, e.g. by aphids carried by air currents, among other things. It is known from the literature that retention of PVY in the stylets of $M$. persicae after acquiring the virus may vary and depends on many factors. Similar results were obtained by Kostiw (1987), who stated in his studies that winged specimens of $M$. persicae may constitute active vectors even after 128 minutes of a lack of contact with the plant, while PVY infection's ability level drops to merely a few per cent. In the case of the winged A. nasturtii, PVY can still be infectious after 17 hours after its acquisition from the source plant. According to Trojanowska (2004) who studied the retention of specific strains of PVY, making use of the Physalis floridana as test plants, the retention period in the stylets of $M$. persicae for PVYN and PVYNTN was only 16 minutes. After this time the aphids lost the capability for further infections.

The use of mineral oil protection had a great effect on PVY. It was found that virus activity in the stylet of $M$. persicae decreased very fast under the influence of the mineral oil previously applied onto the plants. The protection of only the test plants (healthy potato plants cv. Mila from in vitro) resulted in a significant reduction of the effectiveness of the virus transmission after only 16 minutes, and in its complete disappearance be-

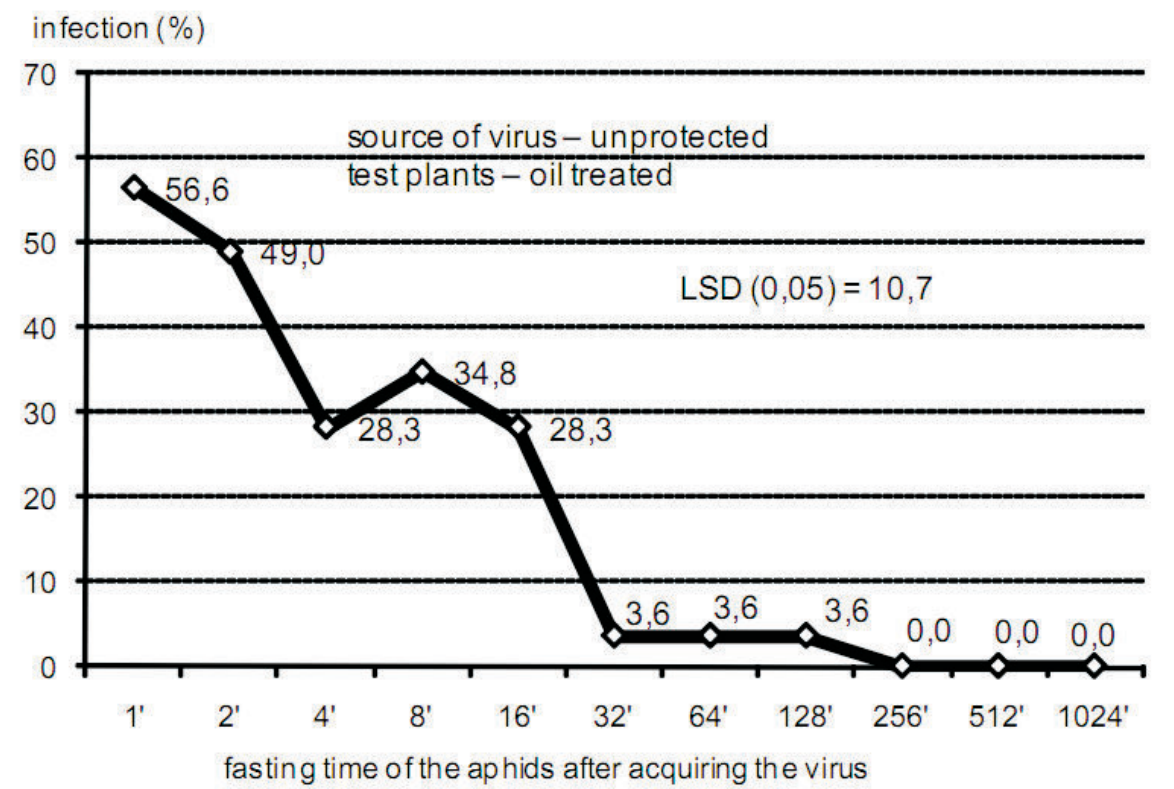

Fig. 2. Impact of mineral oil applied on test plants only for potato virus $Y$ retention in winged $M$. persicae 
tween 128 and 256 minutes of fasting (Fig. 2). After that time the aphid was no longer an active vector of PVY and could not infect the next plants.

The protection of the source of the virus by means of mineral oil contributed to a greater extent of shortening both the retention time and the infection capacity of the virus itself. After using the oil, the infection capacity after two minutes fasting dropped to two plants only and between 8 and 16 minutes fasting of $M$. persicae disappeared completely. It means that PVY

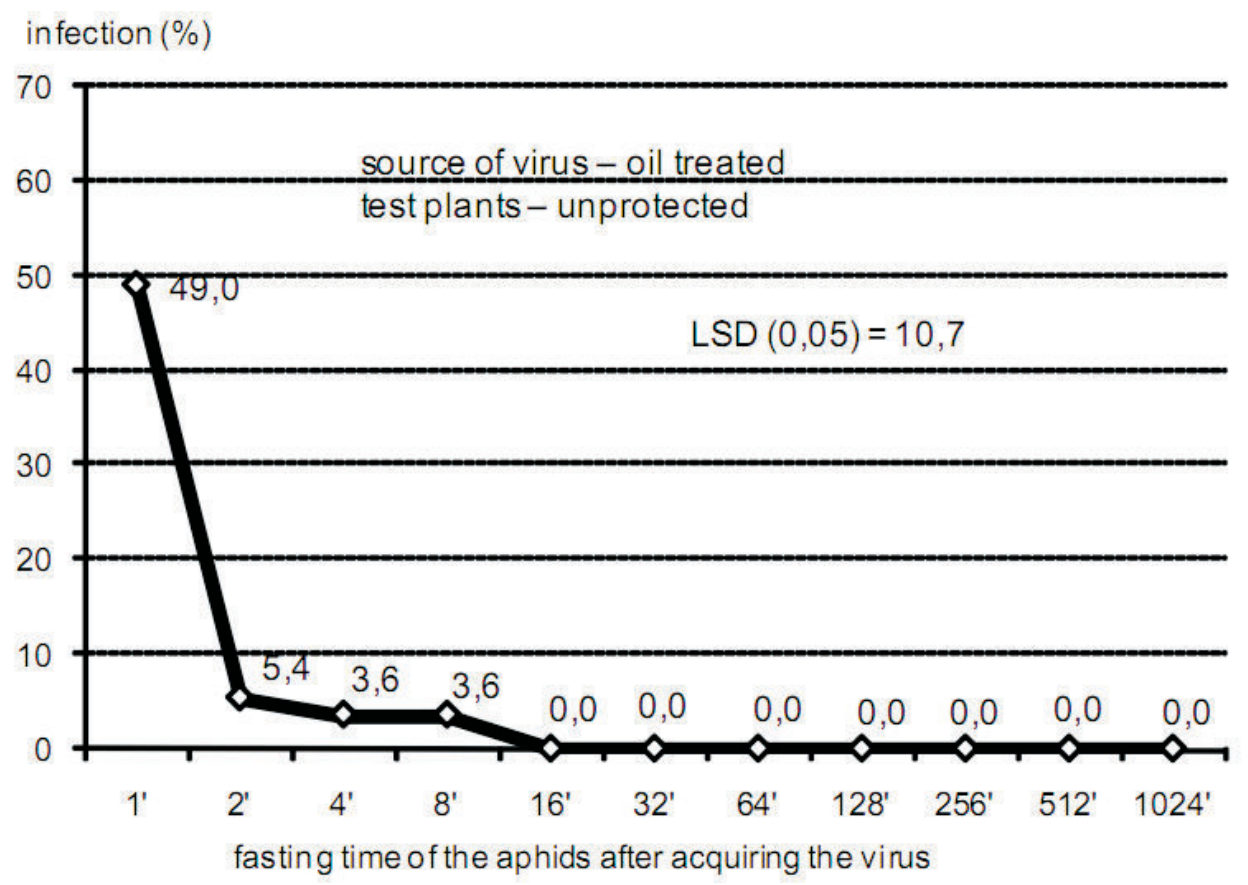

Fig. 3. Impact of mineral oil applied only onto plants being the source of the virus on potato virus $\mathrm{Y}$ retention in winged $M$. persicae

maintained its activity in the aphid's stylet only a few minutes after it was contracted by the aphid (Fig. 3). Interesting results were obtained earlier by Wang and Pirone (1996) who in their research evaluated the ability of $M$. persicae to transfer particles of another virus - TEV (Tobacco etch virus) - marked with radioactive iodine $\left({ }^{125} \mathrm{I}\right)$. They showed that this ability was virtually limited when attempts were made to collect viruses from plants which had been previously treated with mineral oil. However, their research focused on a virus other than PVY and was performed on tobacco plants, and at the same time the effectiveness of TEV transmission to control plants was very low; only $16.7 \%$ of the plants were infected. It is also known that in the case of potato plants, $M$. persicae can, albeit to a very limited extent, contract the virus even from plants which were previously protected with mineral oil. Advanced research into the influence of mineral oil on PVY transmission 
by M. persicae was also conducted by other researchers (Gibson et al. 1988; Powell 1992; Powell and Hardie 1994). The results they obtained point to a significant and limiting influence of mineral oil on the absorption of PVY by $M$. persicae from infected plants. However, none of those studies evaluated the virus retention time in the aphid stylet after its absorption from the plant, instead they focused solely on the infecting ability of $M$. persicae. Therefore the results of our research are the first to unambiguously show the influence of mineral oil on the specific ability of the infective virus to survive temporarily in $M$. persicae stylet.

The shortest retention time, and also the lowest PVY infection ratio, existed in the situation where both the plants being the source of the virus and the potato test plants were protected with mineral oil (Fig. 4). In comparison to the other combinations the plant infection was several times lower (Table 2). It was noted that already after a 1 minute starving time for $M$. persicae, its infection ability was very low, as only 2 out of 10 plants were infected, and after 2 minutes only 1 plant was infected. The aphid ceased to be active vectors between the $2^{\text {nd }}$ and $4^{\text {th }}$ minute of starving, as after a 4 minute of starving no infected plant was noted.

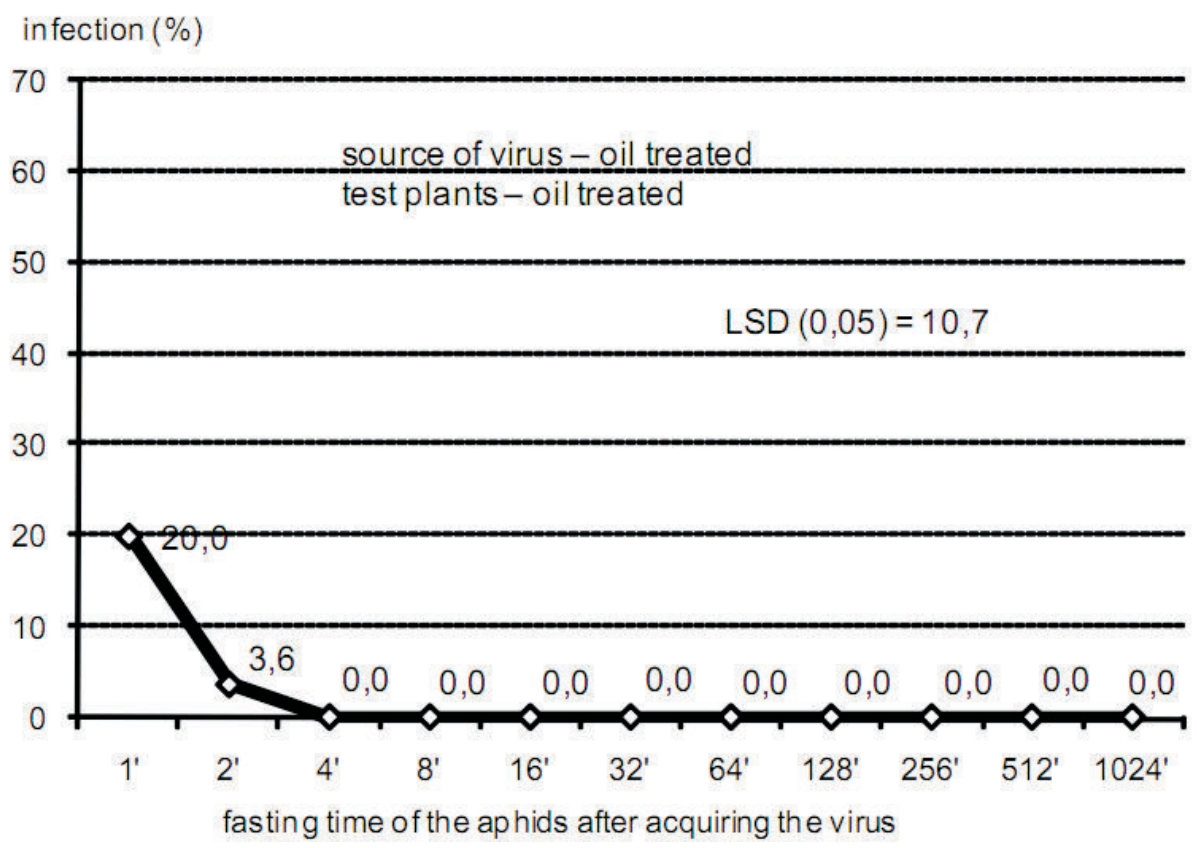

Fig. 4. Impact of the mineral oil applied both on the test plants and the plants being the source of virus on potato virus $\mathrm{Y}$ retention in winged $M$. persicae

The considerable limitation of the activity of the virus in the aphid stylets after the use of mineral oil on the plants, which are the source of the virus, in practice reduces the potential range of infection of healthy plants. Under production conditions, especially when the produced plants are susceptible 
to PVY but at the same time do not show clear symptoms of the disease, there are often many infection sources at plantations. The negative selection of such plants is limited and often made impossible by the lack of infection symptoms. Using mineral oil to protect the plants significantly reduces their importance for the spreading of PVY.

Table 2

The influence of protected potato plants of mineral oil in different combination on infection [\%] of potato tuber by PVY

\begin{tabular}{clll}
\hline No. & Virus source & \multicolumn{1}{c}{ Test plants } & Infection $[\%]^{*}$ \\
\hline 1. & without protection & without protection & $21.5 \mathrm{a}$ \\
2. & without protection & treated with oil & $9.4 \mathrm{~b}$ \\
3. & treated with oil & without protection & $1.9 \mathrm{c}$ \\
4. & treated with oil & treated with oil & $0.6 \mathrm{c}$ \\
\hline
\end{tabular}

* average of infection for all starving times in each combination, retransformation data

Means in the column marked with same letters do not differ significantly $(\alpha=0.01)$

There is no present results describing durability of oil layer on leaves. Field investigations showed that protection by mineral oil is efficient only when treatments are performed regularly (every 7 days). Extending period between treatments lowers efficacy of oil protection and results in enhanced infection (Trujillo-Pinto et al.1989, Turska and Wróbel 1999). However taking into ccount that recommended dose of oil is $151 \times \mathrm{ha}^{-1}$ and $1 \mathrm{~L}$ of oil costs around $9 \mathrm{zl}(2.1 €)$ it is obvious that too frequent treatments have no economical justification. It was observed in field experiments that six days after treatment the layer of Sunspray 850 EC oil was still present on surface of potato plants despite the fact that during this period rain level rated to $64 \mathrm{~mm}$. Thus the durability of oil layer is quite high (Wróbel, unpublished results). According to Powel and Hardy (1994) thickness of oil layer on protected leaves has no influence on limitation of PVY transmissibility by aphids.

Some mineral oils exhibits strong phytotoxic activity towards plants (Northover i Timmer 2002, Traicevski et al. 2002, Goszczyński et al. 2003, Wróbel i Urbanowicz 2007). Such activity was not found for Sunspray 850 EC oil (Wróbel i Urbanowicz 2007). It was observed in field investigations that rainy or hot vegetation periods had no influence on oil efficacy (Wróbel S., unpublished results). During hot days protected plants were in better form that untreated, probably because oil layer limited gas exchange rate (Goszczyński 2003).

Application of mineral oil in control of PVY on potato is especially recommended for protection of PVY-susceptible cultivars (resistance level lower than 5.5) with high qualification grade as well as for protection of valuable breeding lines. 


\section{CONCLUSIONS}

The application of oil for the protection of potato plants against PVY infection resulted in the significant shortening of the virus retention time in the stylet of $M$. persicae.

In the situation of the lack of oil protection, PVY was active on the aphid's stylet even 17 hours after its contraction, whereas the capacity of the virus transmission by the aphids after that period was very low.

Oil protection of both the healthy plants and those being the source of virus very much reduced retention of PVY in the stylet of $M$. persicae, which were its active vectors for only about 2 minutes.

Considerable shortening the virus activity period in the aphids' stylet, after applying mineral oil onto the plants being the source of the virus, in practice can limit the potential infection range of the healthy plants. In potato production when numerous sources of virus occurs in proximity to potato fields, application of mineral oil lowers to great extent their significance for PVY spread.

\section{AKNOWLEDGEMENTS}

I would like to thank Prof. M. Kostiw and Prof. M. Hurej very much for their assistance and precious suggestions while writing this work. Thanks also to Dr hab. J. Styszko, for his help in statistical analysis. I would like to thank anonymous reviewer for his constructive criticism, which improved the paper. The study was done within the framework of research project No 3 P06R 03424, and financially supported by the Ministry of Science and Higher Education.

\section{REFERENCES}

Cerato C., Rongai D., Borgatti S., Tamba M.L. 1994 Studio delle popolazioni afidiche e delle virosi su coulture di patate de seme. Inf. Agrar. 50: 67-72.

Collar J.T., Avilla C., Fereres A. 1997. New correlations between aphid stylet paths and nonpersistent virus transmission. Environ. Entomol. 26: 537-544.

Derron J.O., Goy G. 1990. Importance relative des pucerons ailes les plus frequemment recontres sur la pomme de terre comme vecteurs du virus Y $\left(\mathrm{PVY}^{\mathrm{N}}\right)$, compte tenu de leur mobilite. Rev. Suisse d'Agric. 22: 277-281.

Gibson R.W., Payne R.W., Katis N. 1988. The transmission of potato virus Y by aphids of different vectoring abilities. Ann. Appl. Biol. 113: 35-43.

Goszczyński W., Tomczyk A., Bednarek A. 2003. Wpływ oleju mineralnego Sunspray 850 EC (Ultra Fine) na wymianę gazową liści róż. Prog. Plant Prot. 43 (2): 648-650.

Kamasa J. 2003. Rośliny okopowe - ziemniak: Lista opisowa odmian. Rośliny Rolnicze - 2003. (ed. by R Szymczak) COBORU, Słupia Wielka: 133-161.

Kostiw M. 1976. Wpływ czasu trwania żeru nabycia i żeru inokulacyjnego na efektywność przenoszenia wirusów Y i M ziemniaka przez dwa gatunki mszyc (Myzus persicae Sulz. i Aphis nasturtii Kalt.). Ziemniak: 69-86.

Kostiw M. 1987. Przenoszenie ważniejszych wirusów ziemniaka przez mszyce. Instytut Ziemniaka, praca habilitacyjna, Bonin: 105pp.

Northover J., Timmer L.W., 2002. Control of plant diseases with petroleum- and plant derived oils. In: Beattie G.A.C., Watson D.M., Stevens M.L., Rae D.J., Spooner-Hart R.N., eds. Spray Oils Beyond 2000. University of Western Sydney: 512-526.

Powell G. 1992. The effect of mineral oil on stylet activities and potato virus Y transmission by aphids. Entomol. Exp. Appl. 63: 237-242. 
Powell G. 1993. The effect of pre-acquisition starvation on aphid transmission of potyviruses during observed and electrically recorded stylet penetrations. Entomol. Exp. Appl. 66: 255-260.

Powell G., Hardie J. 1994. Effects of mineral oil applications on aphid behaviour and transmission of potato virus Y. Brighton Crop Protection Conference - Pest and Dis. 1: 229-234.

Powell G., Hardie J., Pickett J.A. 1998. The effects of antifeedant compounds and mineral oil on stylet penetration and transmission of potato virus Y by Myzus persicae (Sulz.) (Hom., Aphididae). J. Appl. Entomol. 122: 331-333.

Qui J.Y., Pirone T.P. 1989. Assessment of the effect of oil on the potyvirus aphid transmission process. J. Phytopathol. 127: 221-226.

Sigvald R. 1984. The relative efficiency of some aphid species as vectors of potato virus $\mathrm{Y}^{0}\left(\mathrm{PVY}^{0}\right)$. Potato Res. 27: 285-290.

Simons J.N., McLean D.L., Kinsey M.G. 1977. Effect of mineral oil on probing behaviour and transmission of stylet-borne viruses by Myzus persicae. J. Econ. Entomol. 70: 309-315.

Traicevski V., Rijswijk B., Hepworth G., Ridland P., Moran J., 2002. Influence of horticultural mineral oil on the incidence of celery mosaic potyvirus in celery. In: Beattie G.A.C., Watson D.M., Stevens M.L., Rae D.J., Spooner-Hart R.N., eds. Spray Oils Beyond 2000. University of Western Sydney: 552-555.

Trojanowska E. 2004. Przenoszenie dwóch szczepów wirusa Y ziemniaka $\left(\mathrm{PVY}^{\mathrm{N}}\right.$ i PVY ${ }^{\mathrm{N}}$ ) przez mszycę brzoskwiniową (Myzus persicae Sulz.). Proceedings of Conference Nasiennictwo i Ochrona Ziemniaka, Kołobrzeg, 4-5.03.2004: 106-109.

Trujillo-Pinto G., Vegas A., Monteverde E. 1989. Control del viruse de la mancha anillada y distorsionante de la lechosa (DRSV) mediante aspersions con aceite blanco. Revista de la Facultad de Agronomia, Universidad Central de Venezuela 15(1-2): 141-155.

Turska E., Wróbel S., 1999: Ograniczenie szerzenia się wirusa Y (PVY) ziemniaka przy użyciu oleju Sunspray 11 E. Progress in Plant Protection Vol.39(2): 841-844.

Wang R.Y., Ammar E.D., Thornbury D.W., Lopez-Moya J.J., Pirone T.P. 1996. Loss of potyvirus transmissibility and helper component activity correlates with non-retention of virions in aphid stylets. J. Gen. Virol. 77: 861-867.

Wang R.Y., Pirone T.P. 1996. Mineral oil interfere with retention of tobacco etch potyvirus in the stylets of Myzus persicae. Phytopathol. 86: 820-823.

Wróbel S., Urbanowicz J. 2007. Reakcja 9 odmian ziemniaka na adiuwanty mineralne i roślinne. Progress in Plant Protection 47 (2): 375-379. 